\title{
Effect of Nitrogen Fertilization on Growth, Yield and Fruit Quality of Superior Grapevines \\ Abd Ollrady, A. A. ${ }^{1}$; S. A. Hegab ${ }^{1}$, H. A. Abd-Eaal ${ }^{2}$ and M. Y. Khalafalla ${ }^{1}$ \\ ${ }^{1}$ Soils \& water Dept., Fac. Agric., Al-Azhar Univ., Assiut, Egypt. \\ ${ }^{2}$ Horticulture Dept., Fac. Agric., Al-Azhar Univ., Assiut, Egypt
}

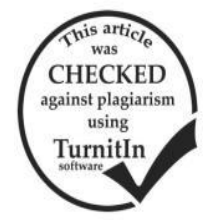

ABSTRACT

This study was conducted during 2017 and 2018 seasons on 5-year old Superior grapevines in a farm located at Minia - Abokerkas western desert road, Egypt. The aim of this investigation was to study the effect of nitrogen sources: (Calcium nitrate $15.5 \% \mathrm{~N}$ as a fast fertilizer and urea form $40 \% \mathrm{~N}$ as a slow fertilizer), with two nitrogen rates (40 and $70 \mathrm{~N}$ units) on the growth and yield of Superior grapevines. The results showed that, the leaf $\mathrm{N}$ content was significantly affected by nitrogen applications. The highest value of leaf $\mathrm{N}$ content was $2.68-8.83 \%$ with 70 units calcium nitrate (F-70) treatment after both seasons. Leaf P content ranged from 0.11 to $0.41 \%$ in both seasons. Leaf $\mathrm{K}$ content was un-significantly affected by either the tested $\mathrm{N}$ sources or their rates, comparing to control $(\mathrm{C})$ treatment. Leaf $\mathrm{K}$ content ranged from 0.79 to 1.41 and 0.69 to $2.00 \%$ in 2017 and 2018 seasons, respectively. Leaf area was significantly affected by fertilizer types or rates. The leaf area (average value) could be arranged in descending order F-70 > F-40 > S-40 > S-70 in both seasons, the highest yield was recorded under urea form 40 units (S-40) and (S-70) treatments. The highest values of total soluble solids, TSS/acid ratio, total sugars, reducing sugars and the lowest values of total acidity were obtained with (S-70) treatment in the second season. Soil nitrogen content, available potassium and available phosphorus was significantly increased by the tested sources rates of fertilizers after the second season compared to the first season. The utilizing of $\mathrm{N}$ fertilizers either as urea form or calcium nitrate elevated the amount of N, P and $\mathrm{K}$ in the soil compared to control.

Keywords: Superior grapevines, nitrogen fertilizers, fruit quality.

\section{INTRODUCTION}

Grape is a popular fruit for both local consumption and international export in many temperate and tropical countries throughout the world. Grape cultivation reached approximately 7.58 million ha world-wide with a total world production of over 68.3 million tons (FAO, 2011). Moreover, it is considered to be the second important fruit crop after citrus in Egypt and it is the fourth crop of a great potentiality for export to world markets. The harvested area (192934 fed) produced 1596169 tons according to the Egyptian Ministry of Agriculture Statistics (2014). Egypt ranks the thirty second position in world-wide (FAO, 2011).

Superior Seedless grape is considered as one of the most important table grape cultivars that requires adequate cultural practices and fertile soil. Fertilization (specially nitrogen) is considered the major factor in this respect taking into account the minimizing accumulation of harmful residual substances such as nitrates and nitrites in the edible berries (Montasser et al., 2003). When nitrogen is a limiting factor, the rate and extent of protein synthesis is decreased. As a result, the plant growth is affected and the plant becomes stunted and develops leaf chlorosis (Vicente et al., 2014).

The quality of grape berries is strongly influenced by nitrogen availability. Soils with high available nitrogen to plant uptake can increase excessive vegetative growth resulting in poor fruit quality due to the shaded canopies. Increasing the quality of grapes can be achieved by controlling soil nitrogen levels through soil management techniques (Wheeler and Pickering, 2003).

The present study aims to examine the effect of different sources and rates of nitrogen fertilizers on growth, yield and fruit quality of Superior grapevines.

\section{MATERIALS AND METHODS}

This study was carried out during two successive seasons 2017 and 2018 in a Farm located at MiniaAbokerkas western desert road, Egypt. Five years-old superior seedless grapevines grown in a sand soil under drip irrigation system and trained to cane pruning under Spanish trellis system, with line spacing 2.0 × $3.0 \mathrm{~m}$ were used.
The experiment was arranged in randomized complete blocks design and five treatments (each replicate 3 vines) with three replicates. The study included two nitrogen fertilizer sources (Calcium nitrate $15.5 \% \mathrm{~N}$ as a fast nitrogen fertilizer and urea form $40 \% \mathrm{~N}$ as a slow nitrogen fertilizer), with two nitrogen rates (40 and 70 units of nitrogen). The treatments were:

1) Slow release nitrogen fertilizer at a rate of $40 \mathrm{~N}$ units noted as $\mathrm{S}-40$

2) Slow release nitrogen fertilizer at a rate of $70 \mathrm{~N}$ units noted as S-70

3) Fast release nitrogen fertilizer at a rate of $40 \mathrm{~N}$ units noted as F-40

4) Fast release nitrogen fertilizer at a rate of $70 \mathrm{~N}$ units noted as F-70

5) Control (without any fertilization) noted as $\mathrm{C}$

Calcium nitrate $(258 \mathrm{~kg}$ and $451 \mathrm{~kg}, \mathrm{~N} / \mathrm{fed})$ was divided into three doses $(25,50$ and $25 \%$ of the total amount). The first dose was added after harvesting the previous vines (2016). The $2^{\text {ed }}$ one was applied through the period from budburst to the begining of bloom and the $3^{\text {rd }}$ one was supplied after fruit set to evasion. While urea form $(100 \mathrm{~kg}$, and $175 \mathrm{~kg}, \mathrm{~N} / \mathrm{fed}$ ) was added one batch to the soil before flowering. The control received no fertilization. All tested vines were fertilized with $\mathrm{P}\left(150 \mathrm{~kg} \mathrm{P}_{2} \mathrm{O}_{5} /\right.$ fed per season $)$ and $\mathrm{K}$ (200 kg K $\mathrm{K}_{2} \mathrm{O} / \mathrm{fed}$ per season). The physical and chemical properties of the experimental soil are shown in Table (1)

Table 1. some physical and chemical soil properties (0-30 cm).

\begin{tabular}{ll}
\hline Properties & Value \\
\hline Sand $(\%)$ & 90.4 \\
Silt $(\%)$ & 5.1 \\
Clay $(\%)$ & 4.5 \\
Texture & Sand \\
pH $(1: 2.5$ suspension $)$ & 8.8 \\
EC $(1: 5) \mathrm{dS} / \mathrm{m}$ & 2.6 \\
Organic matter \% & 0.65 \\
Total Nitrogen \% & 0.09 \\
Available P $\left(\mathrm{mg} \mathrm{kg}^{-1}\right)$ & 7.2 \\
Available K $\left(\mathrm{mg} \mathrm{kg}^{-1}\right)$ & 160 \\
\hline
\end{tabular}


At the end of each season, soil samples were collected from the soil surface to the root zone depth $(0-60 \mathrm{~cm})$ for each vine to determine total nitrogen $(\mathrm{N})$ and available potassium (K) according to Jackson (1973). Available phosphorus was determined by the molybdenum blue colorimetric method (Murphy and Riley, 1962) after extraction by $0.5 \mathrm{M} \mathrm{NaHCO}_{3}$ (Olsen et al., 1954).

Leaf area $\left(\mathrm{cm}^{2}\right)$ mathematically calculated using leaf area-leaf weight relationship from leaf disks obtained by a cork borer Wallace and Munger (1965).

Samples of 5 leaves for each replicate were collected from the first full mature leaves at the fourth week of March in both seasons then leaf petioles were separated from the blades. The petioles were washed with tap water, distilled water, airdried, oven-dried at $70^{\circ} \mathrm{C}$ to constant weight, then ground in a stainless-steel mill and kept for chemical analysis. All samples were subjected to wet digestion using concentrated sulphoric acid and hydrogen peroxide overnight. Nitrogen (\%) was determined by the modified micro kejldahl method as described by Wilde et al. 1985. Phosphorus (\%) was determined by using Olsen method as reported by Chapman and Pratt (1965). Potassium (\%) was flame photometrically determined using the method outlined by Chapman and Pratt (1965).

Also, weight of one year - old pruning wood $(\mathrm{kg}) /$ vine was recorded at the pruning time of each season. At harvesting date (mid/May) when greenish yellow color covered all bunches berries, the yield/vine $(\mathrm{kg})$ was recorded and the number of clusters per vine were counted then the average weight of cluster (g) was recorded.

Numbers of berries from three clusters from each treatment were taken at random to determine the following chemical characteristics:

- Total soluble solids (T.S.S. \%) in the juice using hand refractometer.

- Total acidity (expressed as g. of tartaric acid per $100 \mathrm{ml}$ of juice) by titration with $0.1 \mathrm{~N} \mathrm{NaOH}$ using phenol-phthaline as an indicator.

- Total sugars determined according to the methods described by AOAC (2000).

- Reducing sugars were determined in the juice according to Lane and Eynon procedure as outlined in A.O.A.C. (1985).

- Total Soluble Solids /acid ratio were calculated.

All the obtained data were subjected to statistical analysis using the Duncan's test at $0.05 \mathrm{P}$ level.

\section{RESULTS AND DISCUSSION}

\section{Leaf nutrient content:}

Leaf $\mathrm{N}$ content was significantly affected by nitrogen applications (Table 2).The highest values of leaf $\mathrm{N}$ content (2.68 - 8.83\%) was recorded when soil fertilized by 70 units of calcium nitrate (F-70) after both seasons. In general, leaf $\mathrm{N}$ content ranged from 1.74 to 2.68 and from 1.18 to $8.83 \%$ in 2017 and 2018, respectively. Leaves phosphors content is shown in (Table 2). The highest phosphors $(\mathrm{P})$ value was recorded by adding 70 units calcium nitrate $(\mathrm{F}-70)$ in the first season. There were no significant differences among the treatments in the second one. Leaf $\mathrm{P}$ content ranged from 0.11 to 0.38 and 0.19 to $0.41 \%$ in 2017 and 2018 season, respectively. The leaf $\mathrm{K}$ content was no significantly affected by the tested sources compared to control treatment (C). Leaf $\mathrm{K}$ content ranged from 0.79 to 1.41 and 0.69 to $2.00 \%$ in 2017 and 2018 seasons, respectively (Table 2).

Table 2. Effect of nitrogen fertilizers on leaf nutrient content of Superior grapevines in 2017 and 2018 seasons.

\begin{tabular}{lllllll}
\hline & \multicolumn{6}{c}{ Leaf nutrient content (\%) } \\
\cline { 2 - 7 } Treatments & \multicolumn{5}{l}{ Nitrogen } & \multicolumn{3}{c}{ Phosphorus } & \multicolumn{2}{l}{ Potassium } \\
\cline { 2 - 7 } & $\mathbf{2 0 1 7}$ & $\mathbf{2 0 1 8}$ & $\mathbf{2 0 1 7}$ & $\mathbf{2 0 1 8}$ & $\mathbf{2 0 1 7}$ & $\mathbf{2 0 1 8}$ \\
\hline C & $1.74 \mathrm{c}$ & $1.18 \mathrm{c}$ & $0.11 \mathrm{~d}$ & $0.19 \mathrm{~b}$ & $0.79 \mathrm{~b}$ & $0.69 \mathrm{~b}$ \\
S-40 & $2.65 \mathrm{a}$ & $7.16 \mathrm{~b}$ & $0.29 \mathrm{~b}$ & $0.42 \mathrm{a}$ & $1.37 \mathrm{a}$ & $1.90 \mathrm{a}$ \\
S-70 & $2.43 \mathrm{~b}$ & $6.66 \mathrm{~b}$ & $0.15 \mathrm{~cd}$ & $0.38 \mathrm{a}$ & $1.26 \mathrm{a}$ & $1.80 \mathrm{a}$ \\
F-40 & $2.30 \mathrm{~b}$ & $7.10 \mathrm{~b}$ & $0.20 \mathrm{c}$ & $0.37 \mathrm{a}$ & $1.10 \mathrm{a}$ & $1.69 \mathrm{a}$ \\
F-70 & $2.68 \mathrm{a}$ & $8.83 \mathrm{a}$ & $0.38 \mathrm{a}$ & $0.41 \mathrm{a}$ & $1.41 \mathrm{a}$ & $2.00 \mathrm{a}$ \\
\hline
\end{tabular}

Means denoted by different letters are significantly difference according to Duncan's test at $\mathbf{P}<\mathbf{0 . 0 5}$.

Results in Table (2) clearly reveal that varying nitrogen source applied caused great differences in nitrogen percentages of leaf nutrient content. Also, nitrogen rates from granular calcium nitrate significantly maximized $\mathrm{N} \%$ compared to other form of nitrogen such urea form in the first season. This may be due to that calcium nitrate has high solubility in water than other form of nitrogen sources. Using fast release nitrogen fertilizer (calcium nitrate) and increasing its doses from 40 to 70 units gave significant increase of leaf $\mathrm{N}, \mathrm{P}, \mathrm{K}$ content, in both seasons compared to slow release nitrogen fertilizer (urea form). This may be attributed to the slow release nitrogen need a long time to show its effect. It is well known that increasing $\mathrm{N}$ content in plants resulted in greater uptake of nutrient elements from soil (Marschner, 1995). These results are in accordance with Ghobrial, (2006) and Belal (2006) who mentioned that the highest values of N, $\mathrm{P}$ and $\mathrm{K}$ content in the leaf petioles compared to the other treatments in Thompson seedless grapevines were obtained from using 60 units organic nitrogen.

\section{Chemical properties of berries:}

Data presented in Table (3) show the effect of nitrogen fertilization on some chemical properties (total soluble solids, T.S.S.\%, total acidity, total sugars and reducing sugars) of superior grapevines berries in 2017 and 2018 seasons. T.S.S. ranged from 19.3 to 15.5 in the first season and ranged from 21.5 to 15.3 in the second season. The highest T.S.S. was obtained in vines treated with70 units urea form (S-70) and 70 units calcium nitrate (F-70), respectively after both seasons. Total acidity ranged from 1.7 to 0.8 after two seasons, the highest total acidity was recorded in vines treated with (F-70). The reducing sugars values were 6.0 and 6.3 for (S-70) and (F-70) treatment respectively in the second season. Data showed that both of urea form and calcium nitrate fertilizer application were significantly increased the total sugars in the second season compared to the first one. The highest values of total soluble solids, TSS/acid ratio, total sugars, reducing sugars and the lowest values of total acidity were recorded in S-70 treatment in the second season. The S-70 treatment improved fruit quality expressed by increasing T.S.S, total sugars and decreasing acidity. Ibrahim (2006) and Abbas et al. (2006) concluded that $\mathrm{N}$ application via mineral and bio form improved the berry quality. 
Table 3. Effect of nitrogen fertilization on chemical properties of Superior grapevines berry during 2017 and 2018 seasons.

\begin{tabular}{|c|c|c|c|c|c|c|c|c|c|c|}
\hline \multirow[t]{2}{*}{ Treatments } & \multicolumn{2}{|c|}{$\begin{array}{c}\text { Total soluble } \\
\text { solids }(\%)\end{array}$} & \multicolumn{2}{|c|}{$\begin{array}{c}\text { Total acidity } \\
(\%)\end{array}$} & \multicolumn{2}{|c|}{$\begin{array}{c}\text { Total } \\
\text { sugars }(\%) \\
\end{array}$} & \multicolumn{2}{|c|}{$\begin{array}{l}\text { Reducing } \\
\text { sugars (\%) }\end{array}$} & \multicolumn{2}{|c|}{$\begin{array}{c}\text { Maturity } \\
\text { index(TSS/acidity) }\end{array}$} \\
\hline & 2017 & 2018 & 2017 & 2018 & 2017 & 2018 & 2017 & 2018 & 2017 & 2018 \\
\hline $\mathrm{C}$ & $15.5 \mathrm{c}$ & $15.3 \mathrm{c}$ & $0.8 \mathrm{c}$ & $1.0 \mathrm{c}$ & $8.2 \mathrm{~b}$ & $9.6 \mathrm{~d}$ & $4.1 \mathrm{~b}$ & $4.8 \mathrm{c}$ & 15.3 & 14.9 \\
\hline S-40 & $17.3 b$ & $18.8 b$ & $1.3 \mathrm{a}$ & $1.5 \mathrm{abc}$ & $10.3 \mathrm{a}$ & $11.3 b c$ & $5.0 \mathrm{a}$ & $5.6 a b$ & 13.3 & 12.5 \\
\hline S-70 & $19.3 \mathrm{a}$ & $21.5 \mathrm{a}$ & $1.0 \mathrm{~b}$ & $1.3 b c$ & $10.3 \mathrm{a}$ & 12.1ab & $5.0 \mathrm{a}$ & 6.0ab & 18.7 & 16.6 \\
\hline $\mathrm{F}-40$ & $17.3 b$ & $20.0 \mathrm{ab}$ & $1.2 \mathrm{ab}$ & $1.2 \mathrm{bc}$ & $10.4 \mathrm{a}$ & $11.0 \mathrm{c}$ & $5.1 \mathrm{a}$ & $5.5 b c$ & 18.7 & 17.1 \\
\hline F-70 & $18.3 \mathrm{ab}$ & $21.2 \mathrm{a}$ & $1.2 \mathrm{ab}$ & $1.7 \mathrm{a}$ & $10.4 \mathrm{a}$ & $12.7 \mathrm{a}$ & $5.5 \mathrm{a}$ & $6.3 \mathrm{a}$ & 14.9 & 12.5 \\
\hline
\end{tabular}

Weight of pruning / vine:

The weight of pruning was significantly affected by fertilizing the vines with the rates of calcium nitrate: F-40 and F-70 resulted in maximizing their values in both seasons, followed by S-40 and S-70 treatment (Table 4). The minimum values that recorded in S-40 and S-70 treatment may be ascribed to that $\mathrm{N}$ source from urea form is not adequate and slowly degredate in the soil. The weight pruning wood ranged between 3.6 to $1.7 \mathrm{~kg} / \mathrm{vine}$.

Weight of pruning wood can indicate the vigor status of the vine and refer to its growth during the last summer; such results showed that the F-70 treatment surpassed other treatments in its vegetative growth.

Leaf area:

Results found in Table (4) show the effect of nitrogen fertilization on leaf area of superior grapevines in 2017 and 2018 seasons. Increasing the application rate of both $\mathrm{N}$ source significantly enlargement the leaf area. Moreover, application of 70 units calcium nitrate (F-70) realized more expand of leaf area.

Table 4. Effect of nitrogen fertilizers on yield/vine, leaf area, 100 berries weight and pruning wood of Superior grapevines in 2017 and 2018 seasons.

\begin{tabular}{|c|c|c|c|c|c|c|c|c|}
\hline \multirow{2}{*}{ Treatments } & \multicolumn{2}{|c|}{ Yield/vine (kg) } & \multicolumn{2}{|c|}{100 berries weight $(\mathrm{g})$} & \multicolumn{2}{|c|}{ Pruning wood (kg)/vine } & \multicolumn{2}{|c|}{ Leaf area $\left(\mathrm{cm}^{2}\right)$} \\
\hline & 2017 & 2018 & 2017 & 2018 & 2017 & 2018 & 2017 & 2018 \\
\hline$\overline{\mathrm{C}}$ & $2.81 \mathrm{c}$ & $4.93 \mathrm{c}$ & $445.0 \mathrm{c}$ & $423.3 b$ & $1.8 \mathrm{~d}$ & $1.7 \mathrm{c}$ & $46.6 \mathrm{~d}$ & $57.3 \mathrm{c}$ \\
\hline $\mathrm{S}-40$ & $7.65 \mathrm{a}$ & $9.51 b$ & $483.0 \mathrm{ab}$ & $513.3 \mathrm{a}$ & $2.2 \mathrm{~cd}$ & $3.2 \mathrm{ab}$ & $52.8 \mathrm{c}$ & $61.1 b$ \\
\hline S-70 & $4.96 \mathrm{~b}$ & $11.15 \mathrm{a}$ & $497.3 \mathrm{a}$ & $520.0 \mathrm{a}$ & $2.4 \mathrm{bc}$ & $2.5 b$ & $52.5 \mathrm{c}$ & $61.3 b$ \\
\hline F-40 & $4.66 \mathrm{~b}$ & $8.44 b$ & $469.3 b c$ & $450.0 \mathrm{ab}$ & $2.8 \mathrm{ab}$ & $3.4 \mathrm{a}$ & $56.4 \mathrm{~b}$ & $59.3 b$ \\
\hline F-70 & $3.99 b c$ & $8.17 b$ & $496.3 a$ & $500.0 \mathrm{a}$ & $3.1 \mathrm{a}$ & $3.6 \mathrm{a}$ & $59.7 \mathrm{~b}$ & $69.5 \mathrm{a}$ \\
\hline
\end{tabular}

The leaf area ranged between 69.5 to $46.5 \mathrm{~cm}^{2}$ in both seasons. The leaf area (as average value) could be arranged in descending order of F-70>F-40>S-40>S-70. Abd El-Razek et al., (2011) found that the high nitrogen fertilization improved vegetative growth (leaf area, cane diameter). A linear relationship was noticed between leaf area and nitrogen amount especially when combined with potassium. This may reflect the role of nitrogen as constituent of amino acids and protein as well as the important role of potassium in promoting cell division and development of meristimatic tissue (Grechi et al, 2007).

Yield / vine:

Data in Table (4) show that the yield/vine of superior grapevines was greatly affected by nitrogen fertilization in both seasons. In general, treatments of urea form 40 units (S-40) and (S-70) realized the highest yield values in 2017 and 2018 compared to other treatments. The yield/vine as average value of both seasons could be arranged in descending order of S-40 > S-70 > F-40 > F-70. A significant increase in 'Roomy Red' yield was noticed when the applied nitrogen doses were raised from 20 up to $120 \mathrm{~g}$ $\mathrm{N} /$ vine (Ahmed et al, 1988). There was a gradual increment in the yield of 'Roomy Red' as a result of increasing nitrogen level from 75 to $175 \mathrm{~g} /$ vine (Ghobrial et al, 1991). Furthermore, yield of 'Thompson Seedless' was influenced in positive correlation by the level of nitrogen fertilizers (Salem et al, 2004).

100 berries weight:

The 100 berries weight was significantly affected by rates and types of $\mathrm{N}$ fertilizers (Table 4). The 100 berries weight $(\mathrm{g})$ resulted from 70 units urea form $(\mathrm{S}-70)$ treatment was higher than that resulted from 40 units calcium nitrate $(\mathrm{F}$ 40) treatment in both seasons. The 100 berries weight ranged between $497.3-469.3$ and $520.0-450.0 \mathrm{~g}$ in $1^{\text {st }}$ and $2^{\text {nd }}$ season, respectively. Also, Okamoto et al. (2003) found that fertigated nitrogen with $80 \mathrm{~kg} / \mathrm{ha}$ was attributable to increase berry weight. Abd El-Razek et al, (2011) found that by increasing $\mathrm{N}$-nutrition the single berries were bigger (size, weight) and their shape was not affected.

\section{Soil content of NPK}

Figure 1 represent the effect of nitrogen fertilization on soil nitrogen content of 2017 and 2018 seasons. It is observed that total nitrogen in the first season is less than that of second one. The total nitrogen resulted from urea form treatments was higher than that of calcium nitrate treatments. Total nitrogen measured in calcium nitrate treatments ranged from 0.1 to $0.17 \%$, while in urea form treatments, it differed from 0.14 to $0.19 \%$ in both seasons. The change in soil nitrogen content after both seasons was evident. The negative balance observed in some treatments might be mainly attributed to plant $\mathrm{N}$ uptake and removal. Adekiya et al., (2018) found that the urea fertilizer alone $\left(60 \mathrm{~kg} \cdot \mathrm{ha}^{-1}\right)$ increased the amounts of soil $\mathrm{N}$. The total nitrogen content of soil fertilized by the highest rate of nitrogen was $18 \%$ higher than that in the soil of the control treatment, where no fertilizers were applied (Lemanowicz et al, 2014). 


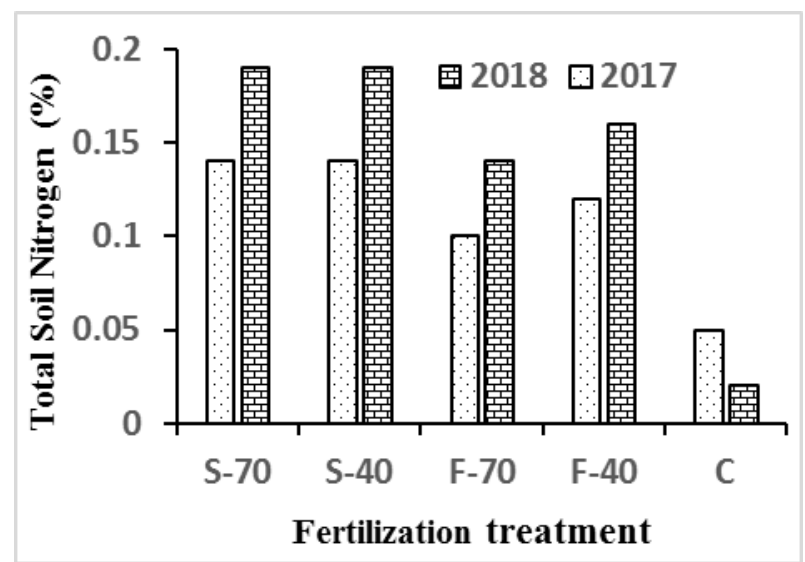

Fig. 1. Effects of nitrogen fertilization on soil total nitrogen in 2017 and 2018 growth seasons.

Data presented in Fig. (2) show the effect of nitrogen fertilization on available phosphors in 2017 and 2018 seasons. Using various nitrogen fertilizer sources obviously affected the amount of available phosphorus. The soil treated with 70 units urea form $(\mathrm{S}-70)$ realized the higher amounts of available phosphorus among the other treatments in both seasons. The lower available phosphorus values of 5.38 and $5.62 \mathrm{ppm}$ were observed in the soil treated with 40 units calcium nitrate (F-40) and that treated with 40 units urea form (S-40), respectively. It was observed that the increase of available phosphorus was associated with the increase of the nitrogen fertilizers in various forms in both seasons. María et al., (2014) indicated that soil organic matter had a positive effect on available phosphorus.

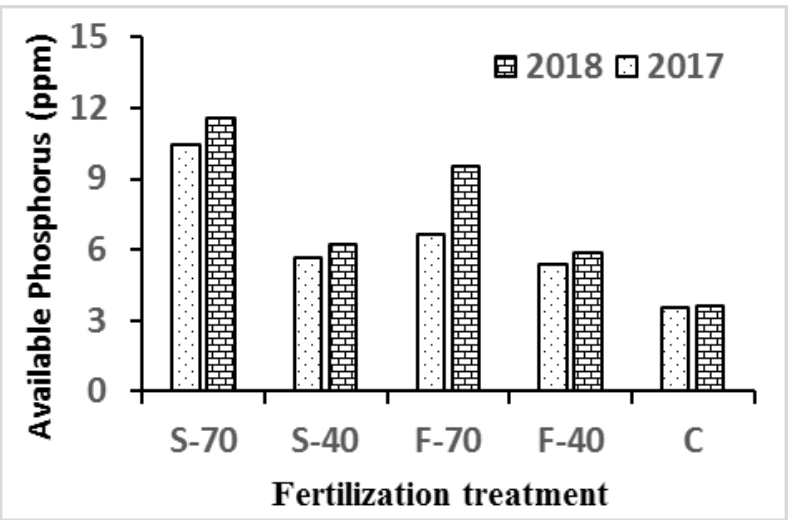

Fig. 2. Effects of nitrogen fertilization on available phosphors in 2017 and 2018 growth seasons.

Data presented in Fig. (3) show the effect of nitrogen fertilizers on available potassium in 2017 and 2018 seasons. Available soil $\mathrm{K}$ was significantly increased in the second season compared to the first one. The highest $\mathrm{K}$ value (267 to $245 \mathrm{ppm}$ ) was recorded with 40 units calcium nitrate (F-40) treatment followed by 40 units urea form (S-40) treatment ( 237 to $216 \mathrm{ppm}$ ) after both seasons. Utilizing $\mathrm{N}$ fertilizers either as urea form or calcium nitrate elevated the amount of $\mathrm{N}, \mathrm{P}$ and $\mathrm{K}$ in the soil compared to control. Application of different sources of $\mathrm{N}$ with combination of potassium sulphate increased the EC of the soil above that of soil fertilized with slow release $\mathrm{N}$ fertilizer alone. Application of $\mathrm{N}$ and potassium sulphate together decreased the $\mathrm{pH}$ and the amounts of $\mathrm{N}$ and $\mathrm{P}$ in the soil, but increased the quantity of potassium, (Awaad et al, 2016).

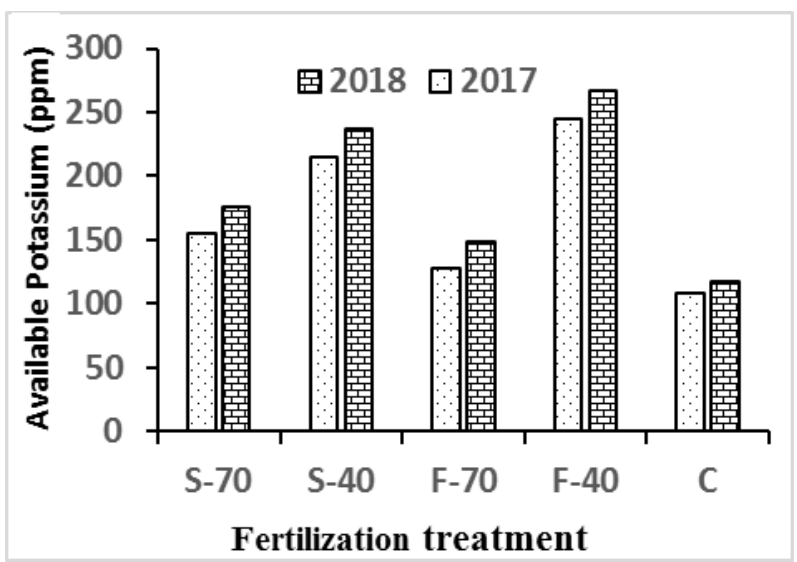

Fig. 3. Effects of nitrogen fertilizers on available potassium in 2017 and 2018 growth seasons.

\section{CONCLUSION}

Slow-release nitrogen fertilizers such as urea form can be used as a pre-plant $\mathrm{N}$ nutrient source. It reduces production costs and eliminates the need for multiple applications of soluble $\mathrm{N}$ fertilizers. Furthermore, slowrelease nitrogen fertilizers were able to decrease nitrate content of plants compared to calcium nitrate application and gave a suitable yield with high cluster and berry traits.

\section{REFERENCES}

A.O.A.C. Association of Official Agricultural Chemists. 1985. Official Methods of Analysis A.O.A.C. Benjamin Franklin Station, Washington, D.C. M.S.A. pp. 440-512.

Abbas, E. S., Bondok, S. A. and Rizk, M. H. (2006). Effect of bio and nitrogen mineral fertilizers on growth and berry quality of Ruby Seedless grapevines. J. Agric. Sci. Mansoura, 31 (7): 4565-4577.

Abd El-Razek, E., Treutter, D., Saleh, M. M. S., ElShammaa, M., Fouad, A. A and Abdel-Hamid, N. (2011). Effect of nitrogen and potassium fertilization on productivity and fruit quality of 'crimson seedless' grape.Agric. Biol. J. N. Am., 2(2): 330-340.

Adekiya, A. O., Aboyeji, C. M., Dunsin, O., Adebiyi, O. V. and Oyinlola, O. T. (2018). Effect of urea fertilizer and maize cob ash on soil chemical properties, growth, yield, and mineral. Journal of Horticultural Research 2018, vol. 26(1): 67-76.

Ahmed, F. F., El-Sayed, M. A. and Maatouk, M. A. (1988). Res? ponse of Red Roomy grapevines to nitrogen application. II.Yield and berries quality. Annals Agric. Sci. Ain Shams Univ., 33, 451-469.

AOAC, (2000). Association of Official Analytical Chemists. Official Methods of Analysis, Washington, DC, USA.

Awaad, M. S., Badr, R. A., Badr, M. A. and Abd-elrahman, A. H. (2016). Effects of different nitrogen and potassium sources on lettuce (Lactuca sativa L.) yield in a sandy soil. Eurasian J. Soil Sci., 5 (4) 299 - 306.

Belal, E. A. (2006). Effect of some kinds of fertilizers on yield and quality of Thompson Seedless grapevines (Vitis vinifera, L.). Ph.D. Thesis, Fac. of Agric., Mansoura Univ. 
Chapman, H. D. and Pratt, P. F. (1965). Methods of analysis of Soils, Plant and Water, Calif Univ. Division of Agric. Sci., pp: 172-173.

Egyptian Ministry of Agriculture Statistics, (2014). Statistics and Economic Affairs Sector, Ministry of Agric. and Land Reclamation, Egypt.

FAO, (2011). Food and Agriculture Organization. Year Book, 52: 146.

Ghobrial, G. H. F., Hassan, F. F. and Rizk, I. A. (1991). Yield and leaf mineral constituents in relation to season frequency of nitrogen applied to Thompson Seedless vineyard. J. Agri. Sci. Mansura Univ., 16, 1854-1858.

Gobrial, S. F. (2006). Minimizing mineral fertilizers in vineyards to reduce the chemical residues in grapes. M. Se. Thesis, Institute of Environmental studies and Research, Ain Shams Univ., Egypt, pp: 67.

Grechi, I., Vivin, P. H., Hilbert, G., Milin, S., Robert, T. and Gaudillère, J. P. (2007). Effect of light and nitrogen supply on internal C: $\mathrm{N}$ balance and control of root-to shoot biomass allocation in grapevine. Envir. and Exp. Bot., 59, 139-149.

Ibrahim A. A. (2006). Influence of some biofertilizers and antioxidants on Red Roomy grapevines (Vitis vinifera L.). Ph.D. Thesis, Fac. Agric., Minia Univ., Egypt, pp. 111.

Jackson, M. L., (1973). Soil Chemical Analysis Constable Co. London. Prentic Hall Inc., EnglwoodCbifis New Jersy.

Lemanowicz, J., Siwik-Ziomek, A. and Koper, J. (2014). Effects of farmyard manure and nitrogen fertilizers on mobility of phosphorus and sulphur in wheat and activity of selected hydrolases in soil. Institute of Agrophysics, Polish Academy of Sciences.

María, D. C., Bernardus, P., Berentsen, M., Oenema, O., Gerard, A., Maria J. and Lansink, O. (2014). Potential for increasing soil nutrient availability via soil organic matter improvement using pseudo panel data. Agricultural Sciences, 5: 743 - 753.
Marschner, H., (1995). Mineral Nutrition of Higher Plants, 2 ed. Academic Press, London.

Montasser, A. S., EL-Shahat N., Ghobreial, G. F. and ELWodoud, M.Z. (2003). Residual effect of nitrogen fertilization on leaves and fruits of Thompson seedless grapes. J. Environ. Sci., 6(2): 465-484.

Murphy, J. and Riley, J. P. (1962). A modified single solution method for the determination of phosphate in natural waters. Anal. Chim. Acta. 26, 31-36.

Okamoto, G., Onishi, H. and Hirano, K. (2003) Effect of fertilizer application levels on anthocyanoplast development in Pione grape skin under a root-zone restricted condition. Am. Soc. Enol. Vitic., 54, PthP Annual Meeting, Reno, Nevada.

Olsen, S. R., Cole, C. V., Watnabe, F. S. and Dean, L. A. (1954). Estimation of Available Phosphorus in Soils by Extraction with Sodium Bicarbonates, vol. 939 of Circular. United States Department of Agriculture, U. S. Department of Agriculture, Washington, DC, USA, 195.

Salem, A. T., Kilany, A. E. and Shaker, G. S. (2004). The influence of NPK, phosphorus source and potassium foliar application on growth and fruit quality of Thompson Seedless grapevines. XXVI International Horticultural Congress: Viticulture Living with Limitations, Toronto, Canada. Acta Hort. 640, 163173.

Vicente, T. O., Oscar, G. V. T., Martha, L. D. P., Héctor, S. N., Antonio, R. M., Rosa, M. M. A., Luis, A. V. A. and Irán, A. T. (2014) Role of Nitrogen and Nutrients in Crop Nutrition. Journal of Agricultural Science and Technology, B4 29-37.

Wallace, O. H. and Munger, H. M. (1965). Studies of the physiological basis for yield differences. 1. Growth analysis of six dry bean varieties. Crop Sci., 5: 343 348.

Wheeler, S. J. and Pickering, G. J. (2003) Optimizing grape quality through soil management practices. Food, Agriculture \& Environment, 1 (2), 190-197.

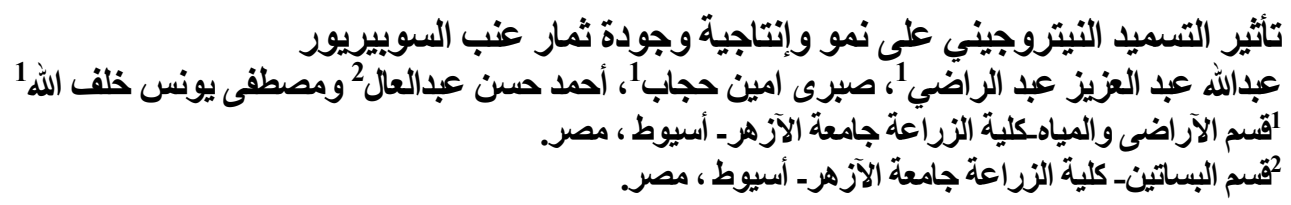

أجريت هذه الدراسة خلال موسمي 2017 و 2018 على كرمات عنب السوبيريور عمر 5 سنوات بمزرعة تقع على على الطريق الصحراوي الغربي

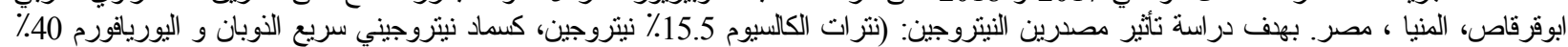

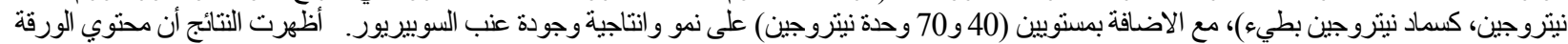

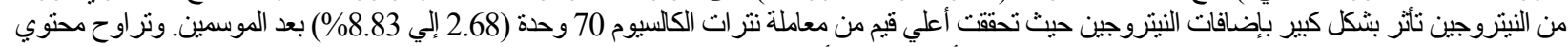

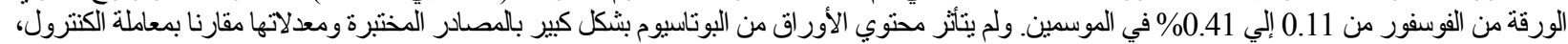

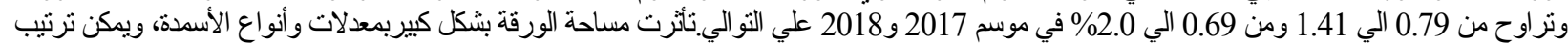

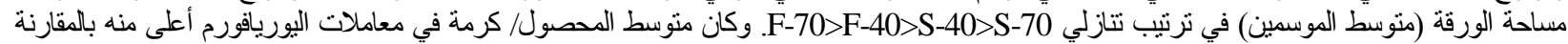

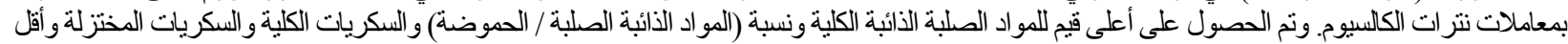

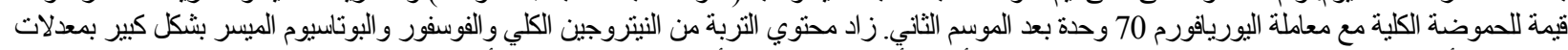

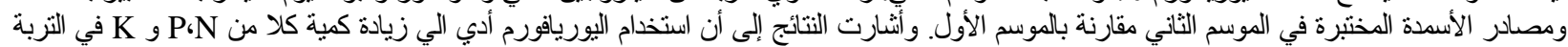
بالمقارنة مع الكنترول. 